\title{
Ariane Boltanski, Les ducs de Nevers et l'État royal. Genèse d'un compromis (ca 1550-ca 1600)
}

\section{Filippo Fassina}

\section{(2) OpenEdition}

1 Journals

\section{Edizione digitale}

URL: http://journals.openedition.org/studifrancesi/8873

DOI: $10.4000 /$ studifrancesi.8873

ISSN: 2421-5856

\section{Editore}

Rosenberg \& Sellier

\section{Edizione cartacea}

Data di pubblicazione: 1 octobre 2008

Paginazione: 443

ISSN: 0039-2944

\section{Notizia bibliografica digitale}

Filippo Fassina, «Ariane Boltanski, Les ducs de Nevers et l'État royal. Genèse d'un compromis (ca 1550-ca 1600)», Studi Francesi [Online], 155 (LII | II) | 2008, online dal 30 novembre 2015, consultato il 14 janvier 2021. URL: http://journals.openedition.org/studifrancesi/8873 ; DOI: https://doi.org/10.4000/

studifrancesi.8873

Questo documento è stato generato automaticamente il 14 janvier 2021.

\section{(c) (1)}

Studi Francesi è distribuita con Licenza Creative Commons Attribuzione - Non commerciale - Non opere derivate 4.0 Internazionale. 


\title{
Ariane Boltanski, Les ducs de Nevers et l'État royal. Genèse d'un compromis (ca 1550-ca 1600)
}

\author{
Filippo Fassina
}

\section{NOTIZIA}

ARIANE BOLTANSKI, Les ducs de Nevers et l'État royal. Genèse d'un compromis (ca 1550-ca 1600), Genève, Droz, 2006 («Travaux d'Humanisme et Renaissance», cdxix), pp. 580.

1 L'A. offre una monografia completa e dettagliata su una delle famiglie più potenti e influenti di Francia nella seconda metà del XvI secolo: i duchi di Nevers, che traevano la propria autorevolezza sia dal prestigio aristocratico, sia dai beni materiali posseduti. Il nucleo fondamentale del presente lavoro è la descrizione dei legami piuttosto complessi instauratisi fra i duchi di Nevers e l'État royal, e lo scopo dichiarato dall'A. è anche quello di chiarire il difficile problema del passaggio dal feudalesimo allo Stato moderno. La prima parte dello studio è dedicata alla genesi e al consolidamento del potere politico e del patrimonio della famiglia, la seconda parte, ai rapporti clientelari (in special modo alla questione della protezione e dei benefici) e la terza parte illustra il ruolo dei duchi all'interno delle Guerres de Religion. Da notare, in appendice, un ricco apparato di tavole genealogiche, di illustrazioni e di indicazioni bibliografiche, che permettono un ulteriore approfondimento su un periodo particolarmente complesso e importante della storia di Francia. 